\title{
Minocycline black bone disease in arthroplasty: a systematic review
}

\author{
William Steadman ${ }^{1,2,3^{*}}$, Zak Brown ${ }^{3}$ and Christopher J. Wall ${ }^{1,3}$
}

\begin{abstract}
Background: Minocycline black bone disease is a rare finding that can cause concern when unexpectedly encountered during routine arthroplasty. Prolonged minocycline use can cause selective staining of subchondral bone, whilst peri-articular soft tissue and cartilage appear uninvolved.

Methods: A systematic review according to PRISMA guidelines was performed to identify all reported cases in the literature. Results: Including the patient we present, eleven cases of minocycline black bone disease encountered during arthroplasty have been reported in the literature. All cases have had an excellent outcome, with no complications reported to date.

Conclusions: Minocycline black bone disease can be a concerning intra-operative finding when unexpectedly encountered during routine arthroplasty, but should not affect the operative plan. Surgeons should exclude alternative causes of bone discolouration when the history is unclear.
\end{abstract}

\section{Introduction}

Discolouration of bone encountered intra-operatively during arthroplasty can be unexpected for the surgeon and raise concerns regarding bone integrity, prosthesis stability and risk of post-operative complications [1]. Despite increasing recognition of minocycline causing bony discolouration, orthopaedic reports remain sparse [2]. Discolouration has been reported as grey, greyishblack, brown, blue-green and black $[1,3]$.

Minocycline is a synthetic tetracycline derivative, with both antibiotic and anti-inflammatory properties. The latter gives it therapeutic properties in rheumatoid arthritis and dermatological conditions such as acne vulgaris and rosacea. Hyperpigmentation can occur in different body tissues, and minocycline is well-recognised as a cause of bony pigmentation in oral and maxillofacial surgery [2]. Differentials for bony discolouration include ochronosis, metabolic bone diseases, metal deposition

\footnotetext{
* Correspondence: uqwstead@uq.edu.au

'Department of Orthopaedics, Toowoomba Hospital, Pechey Street,

Toowoomba, Queensland 4350, Australia

¿University of Queensland, Toowoomba, Queensland, Australia

Full list of author information is available at the end of the article
}

including titanium, iron and copper, haemophilic arthropathy, sequestra, metastases and long-term minocycline use $[1,3]$. Importantly, all of these conditions tend to stain peri-articular tissues, with the exception of minocycline use [1].

Minocycline is strongly bound to plasma proteins, and very lipid soluble, giving it high tissue and body fluid penetrance [4]. In bone, deposits contain iron and calcium, resembling hemosiderin histologically, but lipofuscin, melanin and minocycline degradation products have been implicated in discolouration [4, 5]. Tetracyclines can chelate calcium and be incorporated into normal bone [1]. Currently, there are no reports of pathological bone in adult patients related to minocycline use, although the process of discolouration is rapid and permanent [3]. Ongoing minocycline use may also cause discolouration of operative scars [6].

Dosage required for bony discolouration remains unclear in the literature. Currently reported cumulative exposures can be seen in Table 1 . The minimum reported cumulative dose in arthroplasty literature to cause discolouration is $42.5 \mathrm{~g}$, reported by Yang et al. [7]. 
Histological diagnosis is performed using standard microscopy, which reveals normal bone structure despite macroscopic discolouration $[1,7,8]$. In contrast, other conditions causing discolouration reveal histologic features of infection, infarction or malignancy, or evidence of heavy metal or homogentisic acid deposition $[1,7,8]$. Haematoxylin and eosin and Berlin blue stains may be used to assess samples histologically [1, 7]. Conflicting reports of the utility of ultraviolet fluorescence exist in the literature and may not be a reliable indicator $[3,8]$.

A systematic literature review was performed to evaluate current evidence about minocycline black bone disease in patients undergoing arthroplasty, and its effect on clinical outcomes.

\section{Case report}

A 52-year-old female presented to the orthopaedic outpatient clinic with severe, activity-related, bilateral knee pain, worse on the right side. Clinical examination of her right knee demonstrated medial joint line tenderness, decreased range of motion (ROM) of 15 to 80 degrees, and intact collateral and cruciate ligaments. Radiographs demonstrated advanced tricompartmental osteoarthritis (OA), with complete joint space loss in all compartments.

The patient's past medical history included angina, asthma, gastro-oesophageal reflux disease, and cigarette smoking. The patient had been taking minocycline to treat acne vulgaris for 32 years at $50 \mathrm{mg}$ per day, prior to her initial operation (total exposure of approximately $584 \mathrm{~g}$ ).

The patient had exhausted non-operative treatment for her knee pain. Given that her right knee was clinically and radiographically worse than her left, she was booked for a right total knee arthroplasty (TKA).

Intra-operatively, black staining of the subchondral bone was noted, with no involvement of peri-articular soft tissues or remaining cartilage. The findings were thought to be related to minocycline use and bone specimens were sent for histopathology. TKA was performed using navigation. The patella was resurfaced due to full thickness chondral loss. All components were cemented.

Histology of bone and synovial tissue was consistent with OA, with no other concerning features. The patient made an uneventful recovery. At 12-month review, the patient was pain free with 0 to 130 degree ROM and independent mobility. Slight skin discolouration was noted around the operative scar (Fig. 1). Post-operative radiographs were unremarkable.

The patient complained of worsening left knee pain despite appropriate non-operative treatment. Clinical examination demonstrated mild varus alignment with a limited ROM of 20 to 90 degrees. Radiographs revealed advanced medial compartment OA, with complete joint space loss.

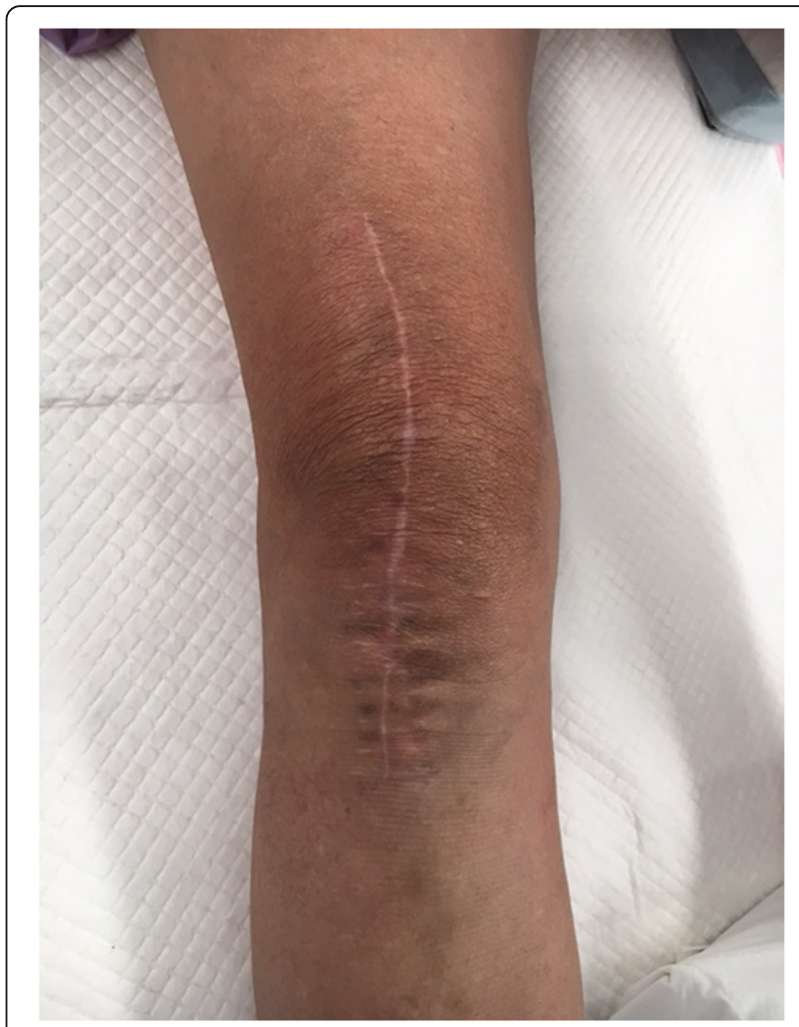

Fig. 1 Operative scar following right total knee arthroplasty

The patient underwent a left TKA 2 years after her contralateral procedure. Black bony discolouration was again noted, with normal peri-articular soft tissues and remaining cartilage (Figs. 2 and 3). TKA was performed using navigation. Patellar osteophytes were removed but the patella was not resurfaced as the cartilage was intact. Both components were cemented. Histopathological examination of the bone was unremarkable. The patient

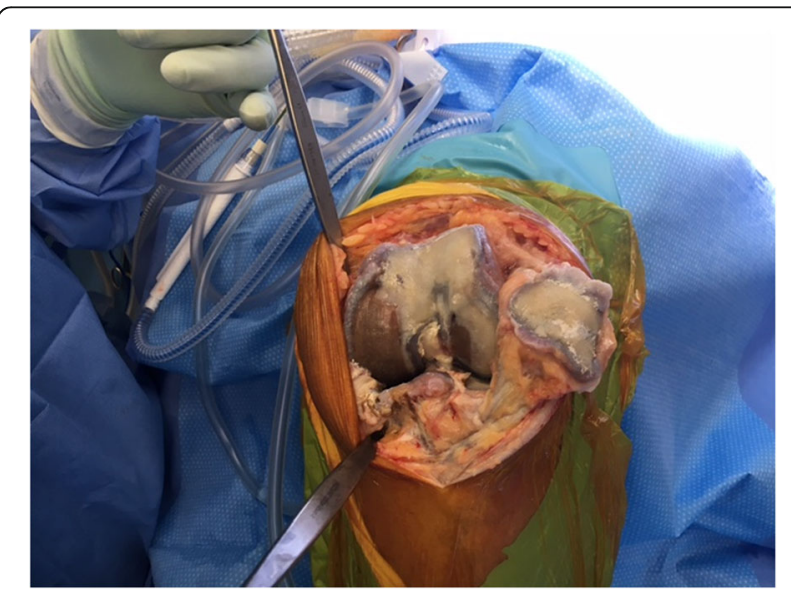

Fig. 2 Femoral surface 


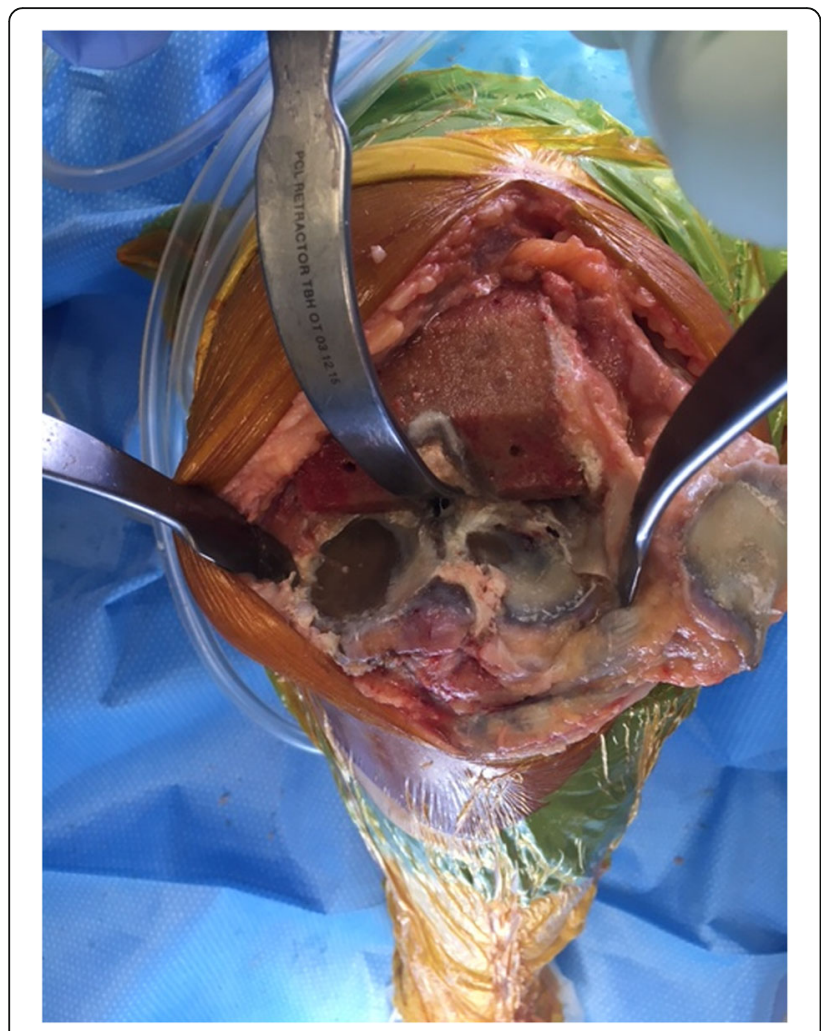

Fig. 3 Tibial surface

made an uneventful recovery. At 12-month review, the patient was pain-free and very satisfied, having returned to full function with ROM of 0 to 120 degrees and a stable knee. Post-operative radiographs were unremarkable.

At final review, 4 years post right TKA and 2 years post left TKA, the patient remained pain free with an excellent functional outcome. Radiographs did not demonstrate any evidence of component loosening or migration.

\section{Materials and methods}

In accordance with Preferred Reporting Items for Systematic Reviews and Meta-Analyses (PRISMA) guidelines, a systematic literature search of MEDLINE, Embase and Cochrane databases was conducted for articles relevant to minocycline bone disease in arthroplasty, on April 15, 2020 [9]. No restrictions were placed on the search, including language or publication year. Search terms included ("MINOCYCLINE" AND ("ARTHROPLASTY" OR "ARTHOPLASTIES" OR “TOTAL JOINT" OR "JOINT REPLACEMENT" OR "PROSTHESIS IMPLAN TATION" OR "JOINT PROSTHESIS" OR "TOTAL ELBOW REPLACEMENT" OR "TOTAL SHOULDER REPLACEMENT" OR "FINGER REPLACEMENT" OR "TOTAL HIP REPLACEMENT" OR "TOTAL KNEE REPLACEMENT" OR "TOTAL ANKLE REPLACEM ENT")). Additional articles were found through manual review of literature and references of relevant articles. Full-text articles were manually screened for relevance by two independent reviewers (W.S. and Z.B.), and discrepancies were discussed until agreed upon.

\section{Results}

A total of 179 articles were found through the structured database search, six were identified for full-text review, and five were included in the article (Fig. 4). All reported cases of minocycline bone disease in arthroplasty, with pre- and post-operative data available are listed in Table 1. A single case series was found, along with four case reports. Data about patient demographics, procedure,

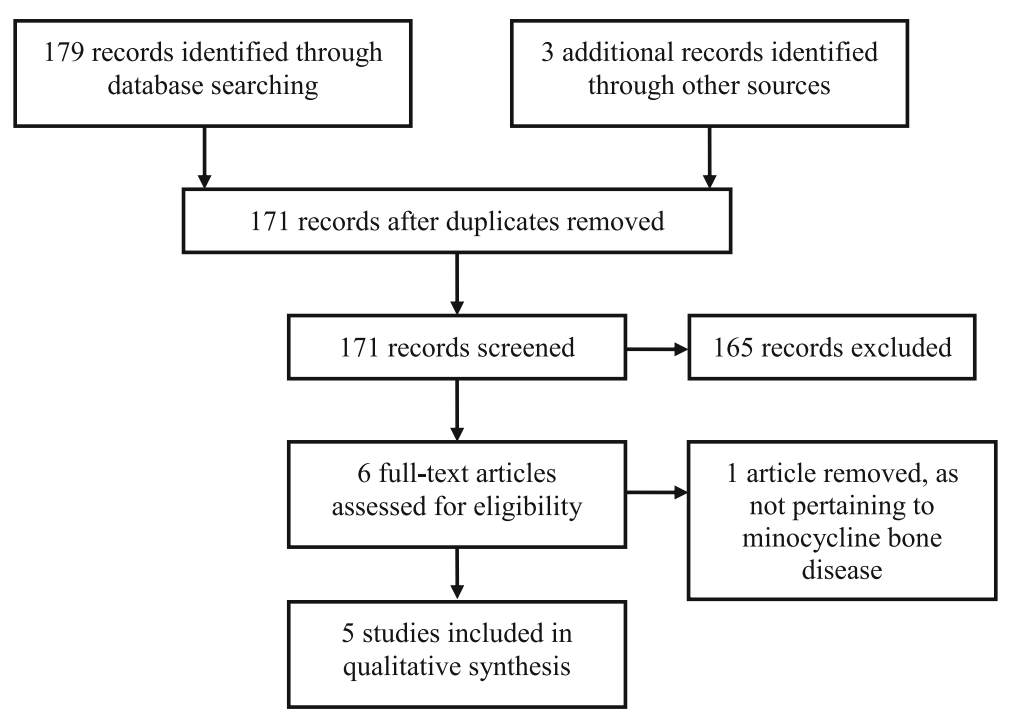

Fig. 4 PRISMA flowchart 
Table 1 Reported Cases

\begin{tabular}{|c|c|c|c|c|c|c|c|c|c|c|}
\hline Study & Age & Joint & Indication & Fixation & Components & $\begin{array}{l}\text { Subchondral } \\
\text { bone }\end{array}$ & $\begin{array}{l}\text { Minocycline dose } \\
\text { (cumulative, g) }\end{array}$ & $\begin{array}{l}\text { Follow-up } \\
\text { (years) }\end{array}$ & $\begin{array}{l}\text { Outcome- } \\
\text { pain }\end{array}$ & $\begin{array}{l}\text { Outcome- } \\
\text { function }\end{array}$ \\
\hline $\begin{array}{l}\text { Ashukem } \\
\text { et al. } \\
\text { (2016) }\end{array}$ & $\begin{array}{l}\text { Not } \\
\text { noted }\end{array}$ & $\begin{array}{l}\text { Primary } \\
\text { shoulder }\end{array}$ & $\mathrm{OA}$ & $\begin{array}{l}\text { Uncemented } \\
\text { stem, } \\
\text { cemented } \\
\text { glenoid }\end{array}$ & $\begin{array}{l}\text { Press-fit humeral } \\
\text { stem, cemented } \\
\text { pegged glenoid } \\
\text { (DJO Turon) }\end{array}$ & Greyish-black & Unspecified & 0.5 & $\begin{array}{l}\text { Little to no } \\
\text { pain }\end{array}$ & $\begin{array}{l}\text { Normal ADLs, } \\
\text { return of ROM, } \\
\text { stable } \\
\text { shoulder }\end{array}$ \\
\hline $\begin{array}{l}\text { Chauhan } \\
\text { and } \\
\text { McDougall } \\
\text { (2014) }\end{array}$ & 82 & $\begin{array}{l}\text { Primary } \\
\text { knee } \\
\text { (bilateral) }\end{array}$ & $\mathrm{OA}$ & & & $\begin{array}{l}\text { Black, normal } \\
\text { cancellous } \\
\text { bone }\end{array}$ & & & & \\
\hline $\begin{array}{l}\text { McCleskey } \\
\text { and } \\
\text { Littleton } \\
(2004)\end{array}$ & 81 & $\begin{array}{l}\text { Primary } \\
\text { knee } \\
\text { (right) }\end{array}$ & $\mathrm{OA}$ & Cemented & Unspecified & $\begin{array}{l}\text { Blue-green- } \\
\text { grey }\end{array}$ & $\sim 73$ & 1 & & $\begin{array}{l}\text { Return of } \\
\text { ROM, stable } \\
\text { knee }\end{array}$ \\
\hline $\begin{array}{l}\text { Reed, } \\
\text { Gregg, and } \\
\text { Corpe } \\
\text { (2012) }\end{array}$ & 55 & $\begin{array}{l}\text { Primary } \\
\text { knee } \\
\text { (left) }\end{array}$ & OA & Cemented & $\begin{array}{l}\text { Not noted, patella } \\
\text { not resurfaced }\end{array}$ & $\begin{array}{l}\text { Black, normal } \\
\text { cancellous } \\
\text { bone }\end{array}$ & $>365$ & 0.25 & No pain & $\begin{array}{l}\text { Normal ADLs, } \\
\text { return of ROM, } \\
\text { stable knee }\end{array}$ \\
\hline \multirow[t]{5}{*}{$\begin{array}{l}\text { Yang et al. } \\
\text { (2012) }\end{array}$} & 75 & $\begin{array}{l}\text { Primary } \\
\text { ankle }\end{array}$ & $\begin{array}{l}\text { Reactive } \\
\text { arthritis }\end{array}$ & & Fine total ankle & Black & 140 & 4.6 & $\begin{array}{l}\text { Occasional } \\
\text { arthritic } \\
\text { pain }\end{array}$ & Normal ADLs \\
\hline & 49 & $\begin{array}{l}\text { Primary } \\
\text { knee }\end{array}$ & RA & & Biomet Vanguard & Black & 131 & 2.8 & No pain & Normal ADLs \\
\hline & 77 & $\begin{array}{l}\text { Revision } \\
\text { knee }\end{array}$ & OA & & $\begin{array}{l}\text { Zimmer Nexgen } \\
\text { LCCK }\end{array}$ & Black & 176 & 2 & \multicolumn{2}{|c|}{$\begin{array}{l}\text { Not noted-multiple } \\
\text { cerebral infarctions at } 2 \text { years }\end{array}$} \\
\hline & 48 & $\begin{array}{l}\text { Primary } \\
\text { hip }\end{array}$ & RA & & $\begin{array}{l}\text { Zimmer ZCA cup } \\
\text { and CPT stem }\end{array}$ & Black & 94.3 & 3.8 & No pain & Normal ADLs \\
\hline & 33 & $\begin{array}{l}\text { Revision } \\
\text { hip }\end{array}$ & Sarcoidosis & & $\begin{array}{l}\text { Zimmer ZCA cup } \\
\text { with JMM KT plate, } \\
\text { Zimmer CPT stem }\end{array}$ & Black & 42.5 & 3.6 & No pain & Normal ADLs \\
\hline \multirow[t]{2}{*}{$\begin{array}{l}\text { This study } \\
\text { (2021) }\end{array}$} & 57 & $\begin{array}{l}\text { Primary } \\
\text { knee } \\
\text { (right) }\end{array}$ & $\mathrm{OA}$ & Cemented & $\begin{array}{l}\text { Stryker Triathlon PS, } \\
\text { patella resurfaced }\end{array}$ & Black & 584 & 4 & No pain & $\begin{array}{l}\text { Normal ADLs, } \\
\text { return of ROM, } \\
\text { stable knee }\end{array}$ \\
\hline & 59 & $\begin{array}{l}\text { Primary } \\
\text { knee } \\
\text { (left) }\end{array}$ & OA & Cemented & $\begin{array}{l}\text { Stryker Triathlon CR, } \\
\text { patella not } \\
\text { resurfaced }\end{array}$ & Black & 621 & 2 & No pain & $\begin{array}{l}\text { Normal ADLs, } \\
\text { return of ROM, } \\
\text { stable knee }\end{array}$ \\
\hline
\end{tabular}

intra-operative findings, histology and clinical and radiographic outcomes was extracted.

Notably, all reported cases had minocycline-related discolouration confirmed on histology. All cases had no discolouration of peri-articular soft-tissues or remaining cartilage, and all had good radiographic alignment and stability on follow-up. Unfortunately, Chauhan et al. did not report on any of these data points.

\section{Discussion}

Minocycline black bone disease is a rare condition that may be encountered unexpectedly during arthroplasty. Based on the findings of this study, surgeons can be reassured that good clinical outcomes can be achieved with routine arthroplasty, and there is no need to alter the operative plan [2]. Other causes of bone discolouration need to be excluded, but sparing of the cartilage and peri-articular soft tissues appears to be indicative of minocycline bone disease [1]. Histopathological evaluation of bone is recommended, as other diagnoses may have significant impacts on post-operative care.
Costal cartilage has previously been reported as darkened with prolonged minocycline use, but no reports of cartilage discolouration exist in the setting of arthroplasty [10]. Peri-articular soft tissues do not appear to be affected by minocycline bone disease. Extra-articular soft tissue discolouration has been previously reported in relation to minocycline use; however, this has not been reported in arthroplasty [4].

When encountering pigmented bone, the orthopaedic surgeon should be aware of potential diagnoses and their associated clinical features to ensure that appropriate steps are taken intra-operatively. Patients with ochronosis develop joint degeneration following cartilaginous erosion, with pigmentation of cartilage, bone and connective tissue. Bony architecture is unchanged [11] and good patient outcomes following TKA have been reported in the literature, but increased risk of osteopenia has been demonstrated $[12,13]$. Heavy metal deposition may be suspected due to medical or occupational history, and serum levels of titanium, iron or copper may be confirmatory. Haemophilic arthropathy may cause early joint degeneration, but this is likely to be clear from the medical history. Infection may 
also be suspected in the presence of stained tissue, especially with sequestra. A full workup for osteomyelitis is indicated with fresh samples sent for culture. This diagnosis is likely to necessitate a change in operative plan due to the significant risk of subsequent prosthetic joint infection. A metastatic process may also require adjustment of operative plan, with increased concern for implant stability or tumour spread. In patients without a previous diagnosis, a tissue biopsy should be performed. Overall, it is important for the orthopaedic surgeon to perform a thorough history and clinical examination, and order appropriate investigations pre-operatively, to ensure this information is available for diagnostic purposes at the time of surgery.

There are limitations to the conclusions that can be drawn from the current body of evidence, as no studies exist at a higher level than case series. Our findings are at significant risk of publication bias, as surgeons may not be willing to publish reports of cases that had a suboptimal outcome. Further reporting of cases will help to determine the prevalence of minocycline black bone disease and the longer-term outcomes post arthroplasty. Reporting of patients' total minocycline exposure may help to find the level at which bony discolouration occurs.

Minocycline black bone disease is a rare finding that can cause concern when unexpectedly encountered during routine arthroplasty. Currently, no reports exist of poor outcomes in the presence of this disease; however, surgeons should exclude alternative causes of bone discolouration when the history is unclear. Selective discolouration of subchondral bone with sparing of periarticular soft tissues and cartilage may be a reassuring clinical sign of minocycline bone disease; however, this requires further investigation.

\section{Abbreviations}

ROM: Range of motion; OA: Osteoarthritis; TKA: Total knee arthroplasty; PRIS MA: Preferred Reporting Items for Systematic Reviews and Meta-Analyses (PRISMA)

\section{Acknowledgements}

Not applicable

\section{Authors' contributions}

All authors contributed to the direction of the research and editing of the manuscript. Dr. William Steadman wrote the original manuscript. Dr. William Steadman and Dr. Zak Brown conducted the systematic review. Dr. Chris Wall supplied the participant for the case report. The authors read and approved the final manuscript.

\section{Funding}

A Toowoomba Hospital Foundation \& Pure Land Learning College Research Grant was received following conclusion of this work to aid in publication.

\section{Declarations}

Ethics approval and consent to participate

Consent was obtained from the patient and local Human Research Ethics Committee approval given for this study.

\section{Consent for publication}

Consent was obtained from the patient and local Human Research Ethics Committee approval given for publication.

\section{Competing interests}

The authors have no relevant conflict of interest to declare for the work under consideration. CW has delivered a paid presentation for Stryker outside of the submitted work.

\section{Author details}

'Department of Orthopaedics, Toowoomba Hospital, Pechey Street, Toowoomba, Queensland 4350, Australia. ${ }^{2}$ University of Queensland, Toowoomba, Queensland, Australia. ${ }^{3}$ School of Medicine, Rural Clinical School, University of Queensland, Toowoomba, Queensland, Australia.

Received: 6 February 2021 Accepted: 14 July 2021

Published online: 04 August 2021

\section{References}

1. Ashukem MT, Levy JC, Formaini N. Minocycline induced black bone disease. Current Orthopaedic Practice. 2016;27(6):698-701.

2. Toffoli A, Gamain R, Lazerges C, Chammas M. Black pigmentation of both forearm bones after chronic minocycline antibiotic therapy for septic nonunion. A case report and literature review. Hand Surg Rehabil. 2019 Feb; 38(1):71-3.

3. McCleskey PE, Littleton KH. Minocycline-induced blue-green discoloration of bone. A case report. J Bone Joint Surg Am. 2004 Jan;86(1):146-8.

4. Eisen DH. Minocycline-induced pigmentation. Incidence, prevention and management. Drug Saf. 1998;18:431-40,

5. Mehrany K, Kist JM, Ahmed DD, Gibson LE. Minocycline-induced cutaneous pigmentation. Int J Dermatol. 2003 Jul;:42(7):551-2.

6. Kobayashi T, Hayakawa K. Minocycline-induced skin pigmentation. Infection. 2017:45(1):129-30.

7. Yang S, Takakubo Y, Kobayashi S, Asano T, Sasaki A, Sasaki K, et al. Minocycline-induced periarticular black bones in inflamed joints which underwent arthroplastic reconstruction. Clinics in Orthopedic Surgery. 2012; 4(3):181-7.

8. Reed DN, Gregg FO, Corpe RS. Minocycline-induced black bone disease encountered during total knee arthroplasty. Orthopedics. 2012 May;35(5): e737-9.

9. Moher D, Liberati A, Tetzlaff J, Altman D. Preferred Reporting Items for Systematic Reviews and Meta-Analyses: the PRISMA statement. PLoS Med. 2009;6(7):e1000097.

10. Attwood HD, Dennett $X$. A black thyroid and minocycline treatment. $\mathrm{Br}$ Med J. 1976 Nov 6;2(6044):1 109-10.

11. Di Franco M, Coari G, Bonucci E. A morphological study of bone and articular cartilage in ochronosis. Virchows Arch. 2000 Jan;436(1):74-81.

12. Aliberti G, Pulignano I, Schiappoli A, Minisola S, Romagnoli E, Proietta M. Bone metabolism in ochronotic patients. J Intern Med. 2003 Sep;254(3):296-300.

13. Lee WC, Tan TL, Chan YH. Total knee arthroplasty in ochronosis arthropathy: a case report and systematic review. Case Rep Orthop. 2019;2019:1871856.

\section{Publisher's Note}

Springer Nature remains neutral with regard to jurisdictional claims in published maps and institutional affiliations. 